\title{
Characterization of Child Maltreatment Cases Identified in Health Services
}

\author{
Davi Manzini Macedo ${ }^{1}$ \\ Priscila Lawrenz ${ }^{2}$ \\ Jean Von Hohendorff ${ }^{3}$ \\ Clarissa Pinto Pizarro Freitas ${ }^{4}$ iD \\ Silvia Helena Koller ${ }^{5}$ \\ Luisa Fernanda Habigzang ${ }^{2}$
}

\begin{abstract}
Child maltreatment is a severe Public Health issue. To understand its associated factors, our study analyzed 14.564 cases of child maltreatment recorded in the state of Rio Grande do Sul between 2010 and 2014. In our study, we analyzed immediate contextual aspects (child's gender and developmental stage, perpetrator's gender, family relationship between the victim and the perpetrator) and intermediate aspects (health professionals' response). Chi-square analysis showed that girls were more likely to be vulnerable to sexual and psychological abuse, especially in middle childhood. Boys, on the other hand, were more likely to experience neglect in infancy and physical abuse in middle childhood. Males were the main perpetrators. Our results are discussed, based on a theoretical review of the sociocultural conceptions of child developmental characteristics, parenting practices, and gender roles. We suggest changes in the notification process and case referral.
\end{abstract}

Keywords: violence in children, childhood, public health

\section{Caracterização de Casos de Maus-Tratos Infantis Identificados em Serviços de Saúde}

Resumo: Os maus-tratos infantis são um grave problema de saúde pública. A fim de elucidar fatores associados à sua ocorrência, no presente estudo foram analisados 14.564 casos de maus tratos contra crianças reportados no Rio Grande do Sul entre 2010 e 2014 . Foram analisados aspectos que operam em níveis contextuais imediatos (gênero da criança e fase do desenvolvimento, sexo do perpetrador, parentesco entre a vítima e perpetrador) e intermediários (respostas do profissional da saúde) dos casos reportados. Resultados de qui quadrado demonstraram que meninas tendem a ser vulneráveis ao abuso sexual e psicológico, principalmente durante a terceira infância. Meninos tendem a ser expostos a maus tratos físicos, na terceira infância, e à negligência na primeira infầncia. Homens foram os principais agressores identificados. Os resultados são discutidos com base em revisão teórica sobre concepções socioculturais de características desenvolvimentais infantis, práticas parentais e papéis de gênero. Sugerem-se modificações no processo de notificação e encaminhamento dos casos.

Palavras-chave: violência na criança, infância, saúde pública

\section{Caracterización de los Casos de Maltrato Infantil Identificados en Servicios de Salud}

Resumen: El maltrato infantil es un grave problema de salud pública. Con el fin de exponer los factores asociados a su ocurrencia, en el presente estudio se analizaron 14.564 casos de maltrato infantil reportados en Rio Grande do Sul entre 2010 y 2014. Se analizaron aspectos que operan a niveles contextuales inmediatos (género del niño y etapa de desarrollo, sexo del perpetrador, parentesco entre la víctima y el perpetrador) e intermediarios (respuestas del profesional de la salud) de los casos reportados. Los resultados del chi-cuadrado mostraron que las niñas tienden a ser vulnerables al abuso sexual y psicológico, especialmente durante su tercera infancia. Los niños tienden a ser expuestos al maltrato físico en la tercera infancia y a la negligencia en la primera infancia. Los principales agresores identificados fueron los hombres. Los resultados se discuten en base a una revisión teórica sobre las concepciones socioculturales de las características del desarrollo infantil, las prácticas parentales y los roles de género. Se sugieren modificaciones en el proceso de notificación y el direccionamiento de casos.

Palabras clave: violencia en niño, infancia, salud pública

${ }^{1}$ University of Adelaide, Adelaide-SA, Australia

${ }^{2}$ Pontificia Universidade Católica do Rio Grande do Sul, Porto Alegre-RS, Brazil

${ }^{3}$ Faculdade Meridional, Passo Fundo-RS, Brazil

${ }^{4}$ Pontificia Universidade Católica do Rio de Janeiro, Rio de Janeiro-RJ, Brazil ${ }^{5}$ Universidade Federal do Rio Grande, Rio Grande-RS, Brazil

Correspondence address: Luísa Habigzang. Avenida Ipiranga, 6681, prédio 11, sala 924. Porto Alegre-RS, Brazil. CEP 90.619-900. E-mail: luisa.habigzang@pucrs.br
Child maltreatment is a severe public health issue on the political agenda worldwide. It consists of all forms of maltreatment that can result in harm to children's health, survival, and development, usually occurring in a relationship of power, trust, and responsibility towards a child (World Health Organization [WHO] \& International Society for Prevention of Child Abuse and Neglect [ISPCAN], 2006). The most common categories of maltreatment in the literature are neglect and 
physical, psychological, and sexual abuse (United Nations Children's Fund [UNICEF], 2014; WHO \& ISPCAN, 2006).

Neglect is defined as the omission of basic needs for physical, emotional and social development (e.g., lack of hygiene, the absence of stimuli, abandonment). Physical abuse is defined as actions that use intentional physical force to cause the victim to suffer damage, wounds, or destruction (e.g. kicking, shoving, and throwing). Psychological abuse, in turn, is seen as any behavior that causes damage to the mental health, self-esteem, identity or development of others (e.g., depreciation, discrimination, rejection). Sexual abuse includes a range of practices to force another to perform any sexual activity through physical strength, coercion or personal influence (e.g., sexual harassment, rape, use of erotic language; UNICEF, 2014; WHO \& ISPCAN, 2006).

The etiology of child maltreatment is influenced by the everyday interaction of children and their families (UNICEF, 2014). Models based on the Bioecological Systems Theory of Human Development (Bronfenbrenner, 1994) have proposed that analysing how factors from different contextual levels interact can contribute to better understanding child maltreatment occurrences. In a more immediate level, characteristics of the children (e.g., developmental stage, gender, personality), caregivers (e.g., gender, relationship with the child, level of education) and familiar environment (e.g., housing conditions, number of occupants) can influence how maltreatment manifests. In an intermediate level, occurrence and perpetuation of child maltreatment may be influenced by the interaction between children, caregivers and the surrounding community, such as schools, community centers, health services and social welfare organizations. In a broader level, sociocultural conceptions about childhood, parenting, gender roles and maltreatment itself can influence how parents respond to child behavior and how other adults that interact with the child (e.g., teacher, health professionals) identify and respond to suspected or confirmed child maltreatment cases (Belsky 1993; Bronfenbrenner, 1994; Cicchetti \& Valentino, 2006).

The Notifiable Disease Information System (SINAN Sistema de Informação de Agravos de Notificação) collects information on cases of child maltreatment identified in the health system (e.g., hospital, emergency stations, health units). On SINAN, details are recorded on characteristics of the victims and perpetrators, particularities of the maltreatment episode, and the referrals made for each case (Ministério da Saúde, 2017). Analysis on a national level demonstrates that child maltreatment cases identified in the Health context occurs mainly in the children's household and is often perpetrated by caregivers. Differences in prevalence rates according to victim's age and gender are also observed (Assis, Avanci, Pesce, Pires, \& Gomes, 2012; Rates, Melo, Mascarenhas, \& Malta, 2015).

The analysis of 17,900 SINAN reports of child victims in 2011 showed that sexual and psychological abuse were more frequently perpetrated against female children aged between 6 and 9 . Neglect was more frequently observed amongst boys aged between 0 and 1 and physical abuse among 6-9 year-old boys. No analysis based on the sex of perpetrators was provided (Rates et al., 2015). Another study analyzed 10,682 SINAN reports on victims aged between 0 and 9 in 2010. Higher prevalence of physical abuse and neglect was observed among boys and psychological and sexual abuse was found to be more common among girls.
The main perpetrators identified were parents. Analysis by perpetrators' gender evidenced the prevalence of males (Assis et al., 2012).

The prevalence of parents as the main perpetrators and the differences between children's and caregivers' characteristics (e.g., age, gender) for the occurrence of different types of maltreatment may indicate the importance of considering sociocultural conceptions of parenting, childhood, and gender roles in understanding the etiology of the phenomena (Belsky, 1993). Attention to factors operating at the intermediate level (Belsky, 1993; Cicchetti \& Valentino, 2006), as the professional's responsive actions to cases, can contribute to increase child maltreatment identification and protective responses (Assis et al., 2012). This analysis can account for the political and institutional aspects commonly involved in public health phenomena (Lynch, 2000) that can contribute to better assessment and reformulation of public policies to reduce child maltreatment occurrence (Assis et al., 2012).

To explore the interaction of factors from different contextual levels in child maltreatment occurrence (Belsky, 1993; Cicchetti \& Valentino, 2006), our study focuses on aspects that operate at the immediate (child gender and developmental stage, perpetrators' gender, relationship between victims and perpetrators) and intermediate (health professionals' response) levels of the cases reported on SINAN. Accordingly, the specific aimsof our study were: (1) to describe characteristics of victims (e.g, gender, developmental stage) and alleged perpetrators (e.g., gender, relationship with the victim) of the child maltreatment cases identified in health care context; (2) to describe details of the child maltreatment episodes (e.g., place of occurrence, number of episodes) identified in the health care context; (3) to verify the interaction between victims' gender and developmental stage and perpetrator's gender for the different types of child maltreatment identified in the health care context; and (4) to characterize the protective actions performed by the health professionals responsible for the cases. Based on the literature of sociocultural concepts of childhood, parenting, and gender roles, we address the sociocultural aspects that influence child maltreatment and the differences between child and perpetrators' characteristics (Belsky, 1993; Cicchetti \& Valentino, 2006).

\section{Method}

\section{Participants}

The sample analyzed corresponded to a SINAN database of 14.564 suspected or confirmed cases of maltreatment of children aged 0-12 years (Law No. 8,069, 1990). The cases were reported between $01 / 01 / 2010$ and 07/31/2014 in the Brazilian state of Rio Grande do Sul. Cases were reported mandatorily during health professionals' daily practice in public and private health services (e.g., hospitals, primary health units, emergency health services), when they identified/suspected of child maltreatment occurrence. After collection procedures, governmental health surveillance agents transferred the data to an electronic database.

\section{Instruments}

The cases were reported through the SINAN Individual Report Form (FIN-SINAN - Ficha Individual de Notificação), 
completed accordingly to Brazilian Ministry of Health prespecified guidelines (Ministério da Saúde, 2008, 2017).

\section{Procedure}

Data collection. Representants of the Health Surveillance Center of Rio Grande do Sul contacted the research team for a partnership aiming to analyze the available data and share the results with health professionals across the state of Rio Grande do Sul. A copy of the data set was then provided after the partnership was formally stablished. Data from 2010 onwards was used, as SINAN data collection started in the whole state of Rio Grande do Sul from this date. After the second half of 2014, a new report form template was proposed, and the analysis of this new cohort is still not published.

Data analysis. The sample was divided into three subgroups according to child's age at the time of report, using criterion from Papalia \& Feldman (2013): (1) infancy (0 - 3 incomplete years); (2) early childhood (3-6 incomplete years); and (3) middle childhood (6-12 incomplete years). The typologies of maltreatment analyzed were: physical, psychological and sexual abuse, and neglect (UNICEF, 2014). Statistically significant associations among categorical variables (developmental stage of victims vs. type of maltreatment, victims' gender vs. type of maltreatment, perpetrators' gender vs. type of maltreatment) were checked through Pearson's chi-square test $\left(\chi^{2}\right)$. Cramer's V was performed to demonstrate the effect size of the $\chi^{2}$. For analysis purposes, missing information was excluded.

\section{Ethical Considerations}

For ethical purposes, all information regarding participant's identification was removed prior to contact with the database. The study was approved by the Ethics Committee of the Pontifícia Universidade Católica do Rio Grande do Sul under the reference number 930.888 .

\section{Results}

Table 1 presents the descriptive analysis of the data (14.564 reports) regarding the sociodemographic characteristics of the child maltreatment victims, according to victims' developmental stage.

The most frequent type of child maltreatment in infancy and early childhood was neglect. For victims in middle childhood, sexual abuse had the highest incidence among the maltreatment cases analyzed. Maltreatment occurred mainly in urban areas and within the victims' households. Table 2 shows the characterization of the child maltreatment cases according to victims' developmental stage.

The prevalence of male perpetrators increased as victims aged, and the inverse occurred in regard to female perpetrators. Parents were the main perpetrators of maltreatment. Table 3 describe perpetrators' characteristics according to the developmental stage of victims.

Table 1

Biological and socio-demographic characteristics of the child maltreatment victims

\begin{tabular}{|c|c|c|c|c|c|c|}
\hline \multirow[t]{2}{*}{ Variable } & \multicolumn{2}{|c|}{ Infancy $(n=5482)$} & \multicolumn{2}{|c|}{ Early Childhood $(n=3260)$} & \multicolumn{2}{|c|}{ Middle Childhood $(n=5822)$} \\
\hline & $n$ & $\%$ & $n$ & $\%$ & $n$ & $\%$ \\
\hline \multicolumn{7}{|l|}{ Gender } \\
\hline Female & 2705 & 49.4 & 1723 & 52.9 & 3307 & 56.8 \\
\hline Male & 2776 & 50.6 & 1536 & 47.1 & 2511 & 43.2 \\
\hline \multicolumn{7}{|l|}{ Race } \\
\hline White & 4407 & 82.0 & 2430 & 79.3 & 4476 & 77.3 \\
\hline Black & 276 & 5.1 & 191 & 6.2 & 429 & 7.4 \\
\hline Yellow & 10 & 0.2 & 8 & 0.3 & 17 & 0.3 \\
\hline Brown & 663 & 12.1 & 432 & 14.1 & 849 & 14.7 \\
\hline Indigenous & 23 & 0.4 & 4 & 0.1 & 19 & 0.3 \\
\hline \multicolumn{7}{|l|}{ Schooling } \\
\hline Incomplete middle school & 00 & 0.0 & 00 & 0.0 & 3812 & 78.5 \\
\hline Incomplete High school & 00 & 0.0 & 00 & 0.0 & 05 & 0.1 \\
\hline Complete High school & 00 & 0.0 & 00 & 0.0 & 01 & 0.01 \\
\hline Illiterate & 00 & 0.0 & 00 & 0.0 & 62 & 1.3 \\
\hline Does not apply & 5482 & 100.0 & 3256 & 100.0 & 977 & 27.8 \\
\hline \multicolumn{7}{|c|}{ Presence of disability and/or disorder } \\
\hline Yes & 163 & 3.0 & 107 & 3.8 & 434 & 8.5 \\
\hline No & 3934 & 97.0 & 2705 & 96.2 & 4692 & 91.5 \\
\hline \multicolumn{7}{|l|}{ Type of Disability } \\
\hline Physical disability & 46 & 0.8 & 19 & 17.9 & 54 & 13.1 \\
\hline Learning disability & 51 & 0.9 & 26 & 25.2 & 153 & 37.2 \\
\hline Visual disability & 14 & 0.3 & 05 & 4.9 & 18 & 4.4 \\
\hline Hearing disability & 02 & 0.001 & 07 & 6.7 & 16 & 4.0 \\
\hline Mental disorder & 19 & 0.4 & 14 & 13.9 & 114 & 28.2 \\
\hline Behavior disorders & 1230 & 22.4 & 23 & 22.1 & 154 & 38.1 \\
\hline
\end{tabular}


Table 2

Frequencies and Percentages of characteristics associated with the child maltreatment reported

\begin{tabular}{|c|c|c|c|c|c|c|}
\hline \multirow[t]{2}{*}{ Variable } & \multicolumn{2}{|c|}{ Infancy $(n=2733)$} & \multicolumn{2}{|c|}{ Early Childhood $(n=3260)$} & \multicolumn{2}{|c|}{ Middle Childhood $(n=4777)$} \\
\hline & $n$ & $\%$ & $n$ & $\%$ & $n$ & $\%$ \\
\hline \multicolumn{7}{|l|}{ Types of Child Maltreatment } \\
\hline Physical Abuse & 1230 & 22.4 & 890 & 29.1 & 2027 & 36.7 \\
\hline Psychological Abuse & 577 & 10.5 & 894 & 29.4 & 2338 & 42.6 \\
\hline Sexual Abuse & 412 & 7.5 & 1123 & 36.7 & 2801 & 50.9 \\
\hline Neglect & 3719 & 67.8 & 1358 & 44.0 & 1406 & 25.5 \\
\hline \multicolumn{7}{|l|}{ Area of Occurrence } \\
\hline Urban & 4733 & 86.3 & 2810 & 92.0 & 4990 & 91.7 \\
\hline Rural & 219 & 4.0 & 174 & 5.7 & 391 & 7.2 \\
\hline Semi-urban & 58 & 1.1 & 24 & 0.8 & 62 & 1.1 \\
\hline \multicolumn{7}{|l|}{ Place of Occurrence } \\
\hline Household & 3862 & 70.4 & 2512 & 81.5 & 4265 & 80.8 \\
\hline Collective Housing & 22 & 0.4 & 18 & 0.6 & 73 & 1.4 \\
\hline School & 66 & 1.2 & 96 & 3.1 & 340 & 6.4 \\
\hline Sports site & 10 & 0.2 & 18 & 0.6 & 37 & 0.7 \\
\hline Bar or similar place & 19 & 0.3 & 8.0 & 0.3 & 23 & 0.4 \\
\hline Public road & 186 & 3.4 & 126 & 4.1 & 429 & 8.1 \\
\hline Trade/Services & 332 & 6.1 & 104 & 3.4 & 110 & 2.1 \\
\hline Others & 498 & 9.1 & 199 & 6.5 & 268 & 4.8 \\
\hline \multicolumn{7}{|l|}{ Recurrence } \\
\hline Yes & 1250 & 22.8 & 1034 & 45.6 & 2768 & 60.8 \\
\hline No & 3954 & 77.2 & 1234 & 54.4 & 1786 & 39.2 \\
\hline \multicolumn{7}{|l|}{ Self-harm } \\
\hline Yes & 00 & 0.0 & 00 & 0.0 & 63 & 1.1 \\
\hline No & 5482 & 100 & 3184 & 100 & 5477 & 98.9 \\
\hline \multicolumn{7}{|l|}{ Means of aggression } \\
\hline Beating & 767 & 14.0 & 835 & 27.0 & 2261 & 41.9 \\
\hline Hanging & 28 & 0.5 & 09 & 0.3 & 29 & 0.5 \\
\hline Blunt object & 91 & 1.7 & 89 & 2.9 & 184 & 3.4 \\
\hline Sharp-cutting object & 111 & 2.0 & 76 & 2.5 & 147 & 2.7 \\
\hline Burning object/substance & 193 & 3.5 & 65 & 2.1 & 63 & 1.2 \\
\hline Poisoning & 141 & 2.6 & 62 & 2.0 & 36 & 0.7 \\
\hline Firearm & 24 & 0.4 & 14 & 0.5 & 50 & 0.9 \\
\hline Threatening & 235 & 4.3 & 376 & 12.2 & 1449 & 27.4 \\
\hline \multicolumn{7}{|l|}{ Forms of sexual violence } \\
\hline Sexual harassment & 87 & 1.6 & 205 & 19.3 & 537 & 19.9 \\
\hline Rape & 250 & 5.4 & 743 & 71.7 & 2028 & 76.7 \\
\hline Indecent assault & 74 & 1.3 & 231 & 22.0 & 512 & 19.1 \\
\hline Child pornography & 09 & 0.2 & 25 & 2.4 & 80 & 3.0 \\
\hline Sexual exploitation & 05 & 0.1 & 20 & 1.9 & 93 & 3.5 \\
\hline \multicolumn{7}{|l|}{ Occurrence of penetration } \\
\hline Oral Penetration & 22 & 0.4 & 129 & 16.3 & 345 & 17.5 \\
\hline Anal Penetration & 47 & 0.9 & 170 & 20.7 & 467 & 22.8 \\
\hline Vaginal Penetration & 52 & 0.9 & 116 & 21.0 & 406 & 26.0 \\
\hline
\end{tabular}

Note. The percentages do not sum-up $100 \%$ due to the presence of missing information for each variable. 
Table 3

Characteristics of perpetrators in the cases of child maltreatment reported

\begin{tabular}{|c|c|c|c|c|c|c|}
\hline \multirow[t]{2}{*}{ Variable } & \multicolumn{2}{|c|}{ Infancy $(n=2733)$} & \multicolumn{2}{|c|}{ Early Childhood $(n=3260)$} & \multicolumn{2}{|c|}{ Middle Childhood $(n=5822)$} \\
\hline & $n$ & $\%$ & $n$ & $\%$ & $n$ & $\%$ \\
\hline \multicolumn{7}{|l|}{ Number of perpetrators } \\
\hline One & 2902 & 55.3 & 2146 & 72.8 & 4069 & 74.9 \\
\hline Two or more & 1918 & 36.5 & 803 & 27.2 & 1366 & 25.1 \\
\hline \multicolumn{7}{|l|}{ Gender of perpetrators } \\
\hline Male & 992 & 20.9 & 1389 & 50.1 & 3592 & 67.6 \\
\hline Female & 1982 & 36.2 & 801 & 28.9 & 947 & 17.8 \\
\hline Both sexes & 1514 & 27.6 & 582 & 21 & 776 & 14.6 \\
\hline \multicolumn{7}{|l|}{ Perpetrators } \\
\hline Mother & 3520 & 64.2 & 945 & 32.1 & 1382 & 25.5 \\
\hline Father & 1952 & 35.2 & 1315 & 43.8 & 1495 & 27.4 \\
\hline Stepmother & 421 & 7.7 & 223 & 7.5 & 732 & 13.5 \\
\hline Stepfather & 115 & 2.1 & 36 & 1.2 & 70 & 1.3 \\
\hline Stranger & 96 & 1.8 & 56 & 1.9 & 232 & 4.3 \\
\hline Brother/sister & 70 & 1.3 & 78 & 2.6 & 201 & 3.7 \\
\hline Friend & 145 & 2.6 & 276 & 9.3 & 1046 & 19.3 \\
\hline Caregiver & 101 & 1.8 & 74 & 2.5 & 95 & 1.8 \\
\hline Boss & 00 & 0.0 & 00 & 0.0 & 09 & 0.2 \\
\hline Person with institutional relationship & 33 & 0.6 & 21 & 0.7 & 88 & 1.6 \\
\hline Police officer/Law enforcement officer & 05 & 0.1 & 00 & 0.0 & 04 & 0.1 \\
\hline The victim himself (self-aggression) & 00 & 0.0 & 78 & 2.6 & 125 & 2.3 \\
\hline \multicolumn{7}{|l|}{ Alcohol intake by perpetrators } \\
\hline Yes & 508 & 9.3 & 447 & 23.1 & 1169 & 32.3 \\
\hline No & 2340 & 42.7 & 1485 & 76.9 & 2446 & 67.7 \\
\hline
\end{tabular}

Note. The percentages do not total $100 \%$ due to the presence of missing information for each variable.

The main consequences of the child maltreatment cases, identified by the health professionals, were Post-Traumatic Stress Disorder (PTSD) and Behavioral Disorders (8.4\%). However, the descriptions of these variables were limited by a considerable rate of missing cases. The number of absent information was also high for variables related to alcohol intake by perpetrators $(n=5602,38.5 \%)$, suicide attempts by victims $(n=4598,31.5 \%)$ and victims' mental disorders $(n=4072,31.1 \%)$. The data also showed that the prophylaxis for sexually transmitted diseases (STDs) in cases of sexual abuse increased accordingly to victims' age, although the percentage was still not expressive. The majority of the notified cases was considered confirmed by the health professional responsible for notifying the case. Table 4 describes the consequences for maltreatment, the referrals of victims to support services, and confirmation status of cases, per victims' developmental stage.

The results of the Pearson's Chi-square analyses confirmed that there was an increase in number of child maltreatment notifications for older children. Middle childhood showed a statistically significant difference for the total number of reported cases $(\chi 2(2)=797.63$, $\rho \leq 0.001$ ) when compared with infancy and early childhood. A Chi-square analysis of type of maltreatment by age group indicated that children in middle childhood were more likely to experience physical abuse $(\chi 2(4)=331.83, \rho \leq 0.001$, $V=.11)$, sexual abuse $(\chi 2=2335.76, \rho \leq 0.001, V=.29)$ and psychological abuse $(\chi 2(4)=1383.28, \rho \leq 0.001, V=.23)$ when compared with those in infancy and early childhood. Children in infancy were more likely to experience neglect $(\chi 2(4)=60.48, \rho \leq 0.001, V=.11)$ when compared with the other two groups.

A Chi-square analysis of the maltreatment occurrence by victims' gender indicated that girls $(\chi 2(2)=7317.01, \rho \leq 0.001)$ were more likely to be maltreated when compared to boys. Differences according to gender and type of maltreatment were also observed within each developmental stage. In infancy, female victims were more likely to suffer sexual $\left(\chi^{2}(4)=\right.$ $110.40, \rho \leq 0.001, V=.10)$ and psychological abuse $(\chi 2(4)=$ $40.14, \rho \leq 0.001, V=.06$ ) when compared with the male victims, whereas male victims were more likely to experience neglect $(\chi 2(4)=60.48, \rho \leq 0.001, V=.08)$. The Chi-square analysis showed no statistically significant difference between victim's gender for the occurrence of physical abuse in infancy. 
Table 4

Consequences for victims, referrals, progression and final classification of reported child maltreatment

\begin{tabular}{|c|c|c|c|c|c|c|}
\hline \multirow[t]{2}{*}{ Variable } & \multicolumn{2}{|c|}{$\begin{array}{c}\text { Infancy } \\
(n=2733)\end{array}$} & \multicolumn{2}{|c|}{$\begin{array}{l}\text { Early Childhood } \\
\qquad(n=3260)\end{array}$} & \multicolumn{2}{|c|}{$\begin{array}{l}\text { Middle Childhood } \\
\quad(n=5822)\end{array}$} \\
\hline & $n$ & $\%$ & $n$ & $\%$ & $N$ & $\%$ \\
\hline \multicolumn{7}{|l|}{ Consequences of violence } \\
\hline PTSD & 209 & 3.8 & 267 & 13.3 & 802 & 20.1 \\
\hline Suicide attempt & 00 & 0.0 & 00 & 0.0 & 24 & 0.6 \\
\hline Behavioral disorders & 130 & 2.4 & 269 & 13.3 & 707 & 17.5 \\
\hline Mental disorders & 14 & 0.3 & 19 & 0.9 & 85 & 2.1 \\
\hline Pregnancy & 00 & 0.0 & 00 & 0.0 & 10 & 1.3 \\
\hline STD Contraction & 24 & 0.5 & 32 & 2.2 & 79 & 2.8 \\
\hline \multicolumn{7}{|l|}{ Health Procedures -VS } \\
\hline Prophylaxis for STD & 21 & 0.4 & 64 & 6.5 & 205 & 8.2 \\
\hline Prophylaxis for HIV & 17 & 0.3 & 65 & 6.6 & 176 & 7.0 \\
\hline Prophylaxis for Hepatitis B & 15 & 0.3 & 39 & 4.0 & 134 & 5.3 \\
\hline Blood sampling & 37 & 0.7 & 96 & 9.7 & 300 & 11.8 \\
\hline Vaginal discharge sampling & 11 & 0.2 & 29 & 4.4 & 96 & 5.3 \\
\hline Semen sampling & 350 & 6.4 & 14 & 1.4 & 47 & 1.9 \\
\hline Emergency contraception & 00 & 0.0 & 05 & 0.8 & 34 & 1.9 \\
\hline Legal Abortion & 00 & 0.0 & 00 & 0.0 & 2 & 0.2 \\
\hline \multicolumn{7}{|l|}{ Health referrals } \\
\hline Outpatient clinic & 2696 & 49.2 & 2153 & 85.8 & 4172 & 91.4 \\
\hline Hospital & 1053 & 19.2 & 356 & 14.2 & 391 & 8.6 \\
\hline \multicolumn{7}{|l|}{ Referrals to network services } \\
\hline Guardianship Council & 3004 & 54.8 & 2136 & 71.0 & 4435 & 80.8 \\
\hline Child and Juvenile Courts & 176 & 3.2 & 203 & 6.9 & 444 & 8.3 \\
\hline Home/Shelter & 70 & 1.3 & 58 & 2.0 & 159 & 3.0 \\
\hline Sentinel Program & 29 & 0.5 & 74 & 2.5 & 242 & 4.5 \\
\hline Women police station & 49 & 0.9 & 38 & 1.3 & 91 & 1.7 \\
\hline Child and adolescent police station & 136 & 2.5 & 238 & 8.0 & 573 & 10.7 \\
\hline Other police station & 260 & 4.7 & 179 & 6.0 & 525 & 9.7 \\
\hline Public Federal Prosecutor & 219 & 4.0 & 330 & 11.2 & 863 & 16.1 \\
\hline Women's Reference Center & 19 & 4.0 & 16 & 0.5 & 22 & 0.4 \\
\hline CRAS or CREAS & 245 & 4.5 & 397 & 13.4 & 1211 & 22.4 \\
\hline Institute of Forensic Medicine & 254 & 4.6 & 599 & 20.2 & 1539 & 28.6 \\
\hline \multicolumn{7}{|l|}{ Progression of cases } \\
\hline Discharge & 3252 & 59.3 & 2386 & 94.2 & 4422 & 96.2 \\
\hline Death by violence & 47 & 0.9 & 10 & 0.4 & 17 & 0.4 \\
\hline Escape & 377 & 6.9 & 133 & 5.3 & 151 & 3.3 \\
\hline Death by other causes & 28 & 0.5 & 03 & 0.1 & 05 & 0.1 \\
\hline \multicolumn{7}{|l|}{ Final classification } \\
\hline Confirmed & 3576 & 67.2 & 1766 & 55.3 & 2877 & 52.8 \\
\hline Discarded & 279 & 5.2 & 144 & 4.5 & 163 & 3.0 \\
\hline Likely & 1068 & 20.1 & 1090 & 34.1 & 2406 & 44.2 \\
\hline Inconclusive & 402 & 7.5 & 193 & 6.0 & 274 & 4.8 \\
\hline
\end{tabular}

Note. The percentages do not total $100 \%$ due to the presence of missing information for each variable. 
In early childhood, the Chi-square analysis showed that male victims were more likely to experience physical abuse $(\chi 2(4)=22.20, \rho \leq 0.001, V=.08)$ and neglect $(\chi 2(4)=59.65$, $\rho \leq 0.001, V=.14)$ when compared tofemale victims. However, female victims were more likely to suffer psychological $(\chi 2(4)=21.06, \rho \leq 0.001, V=.08)$ and sexual abuse $(\chi 2(4)$ $=160.30, \rho \leq 0.001, V=.23)$. In middle childhood, the same pattern was observed. Male victims were at higher risk of physical abuse $(\chi 2=159.49, \rho \leq 0.001, V=.17)$ and neglect $(\chi 2=153.29, \rho \leq 0.001, V=.17)$ when compared to female victims. Female victims were more likely to suffer psychological $(\chi 2=25.83, \rho \leq 0.001, V=.07)$ and sexual abuse $(\chi 2=532.96, \rho \leq 0.001, V=.31)$.

A Chi-square analysis of the gender of perpetrators by maltreatment occurrence, without distinction between types of maltreatment, showed that males were more likely to maltreat children $(\chi 2(3)=5224.64, \rho \leq 0.001)$ when compared to females. Within each developmental stage, a Chi-square analysis of type of maltreatment by perpetrators' gender showed that in infancy male perpetrators were more likely to subject children to psychological $(\chi 2(6)=493.33$, $\rho \leq 0.001, V=.23)$, physical $(\chi 2(6)=626.25, \rho \leq 0.001$, $V=.26)$ and sexual $(\chi 2(6)=1159.34, \rho \leq 0.001, V=.36)$ abuse, whereas female perpetrators were more common in cases of neglect $(\chi 2(6)=1512.17, \rho \leq 0.001, V=.40)$.

In early childhood, the male perpetrators were more likely to subject children to psychological $(\chi 2(2)=66.03$, $\rho \leq 0.001, V=.16)$, physical $(\chi 2(2)=25.78, \rho \leq 0.05$, $V=.10)$ and sexual abuse $(\chi 2(2)=1227.09, \rho \leq 0.001$, $V=.68)$. Reports of neglect were significantly associated with the female perpetrators $(\chi 2(2)=803.22, \rho \leq 0.001$, $V=.55)$. In middle childhood, the male perpetrators were more likely to be physically $(\chi 2(2)=83.92, \rho \leq 0.001, V=.13)$ and sexually $(\chi 2(2)=1972.88, \rho \leq 0.001, V=.62)$ abusive than female perpetrators. Male perpetrators were also more likely to be psychologically abusive, although the effect size was small $(\chi 2(2)=23.73, \rho \leq 0.001, V=.07)$. There were no significant differences regarding the gender of perpetrator for the occurrence of neglect in this developmental stage.

\section{Discussion}

The analyzed reports showed the same patterns observed in SINAN reports on child maltreatment cases on a national level, such as preponderance of occurrence in the victims' households, parents as the most frequent perpetrators, and differences between child age and gender and types of maltreatment (Assis et al., 2012; Rates et al., 2015). These similarities suggest that the state of Rio Grande do Sul does not present any particular feature in the manifestation of child maltreatment. The fact that most of the victims in this sample were Caucasian can be explained by the preponderance of Caucasians in the state of Rio Grande do Sul due to its colonization by Germans and Italians in the XIX century (Instituto Brasileiro de Geografia e Estatística [IBGE], 2011). Notwithstanding, the lack of studies analyzing characteristics of victims and perpetrators within types of maltreatment in other regions limits intra-territorial comparisons (Macedo, D.M., Foschiera, L. N., Bordini, T. C. P. M., Habigzang, L. F., \& Koller, S. H, 2019). Differences in implementation levels of epidemiological surveillance of child maltreatment across the national territory can be another limitation for comparison purposes (Assis et al., 2012).

\section{Differences between victims' developmental stage and gender and perpetrators' gender for types of child maltreatment}

Infancy is a period when the child is physically fragile and more dependent on parental care (Papalia \& Feldman, 2013). The higher prevalence of cases of neglect that required health assistance among infant children may be a consequence of parents' poor knowledge of the child's needs (e.g., nurturing and regular feeding) and the impact of poor care in such a sensitive developmental stage (Weber, Viezzer, Brandenburg, \& Zocche, 2002). Moreover, since parenting is influenced by sociocultural factors and education attainment (Rodriguez, 2010), differences in parent's conceptualization of care and maltreatment may also play a role. A national study emphasized that neglectful parents were unaware of the term "neglect". These parents tended to conceptualize maltreatment only when visible consequences were present. Therefore, they failed to identify its occurrence and to pursuit support (Delfino, Biasoli-Alves, Sagim, \& Venturini, 2005), possibly leading to poor health outcomes.

Sociocultural concepts about parenting and children upbringing can also contribute to the explanation of higher prevalence of physical and psychological abuse in middle childhood. The increased levels of child interaction with the wider family and surrounding community can trigger behavioral changes incompatible with parental expectations (Boudreaux \& Lord, 2005). Thus, caregivers can be more likely to be abusive as they expect punitive practices to change childrens' behaviors (Donoso \& Ricas, 2009). Parents can also assume intentionality to emotions and behaviors consistent with the child age, such as environmental exploitation and crying, and apply violent punishment expecting behavioral change (Weber et al., 2002).

The higher incidence of physical abuse among boys can reflect differences in the socialization of boys and girls. Socially encouraged behaviors based on gender diffenreces are learned by children from preschool age and are established across childhood (Halim, Ruble, Tamis-LeMonda, \& Shrout, 2013). Boys and men are socially expected to exhibit dominant attitudes, express anger, and suppress fear and helplessness (García, 2014). As boys tend to show more aggressiveness, physical punishments tend to be more severe when compared to the girls' cases (Lysenko, Barker, \& Jaffee, 2013); and since the use of harsh discipline amongst boys is associated with increase in child's defiant behavior (Meier, Slutske, Heath, \& Martin, 2009), it is possible that maltreatment starts as a dysfunctional parenting practice that can escalate and lead to severe physical punishment, requiring health professionals' attention more frequently. 
Child developmental characteristics, such as the manifestation of secondary sexual characteristics, might contribute to the higher prevalence of sexual abuse in middle childhood (Alves, Silva, \& Silva, 2012). Beyond such biological aspect, the cognitive development of the child and advances in the process of socialization can also help them understand the nature of this experience and seek for assistance (Baía, Veloso, Magalhães, \& Dell'Aglio, 2013). Abusive sexual practices can start early and only be disclosed or revealed as the child ages (Spiegel, 2003). Concerns about the consequences of the sexual abuse (e.g., sexually transmitted diseases, pregnancy) by caregivers and health professionals might also contribute to its higher notification in the health system when compared with other forms of abuse amongst older children (Assis et al., 2012).

Moreover, sociocultural views of gender mightay also interact to shape child maltreatment. The prevalence of female victims in the sexual abuse cases can be linked to patterns of male dominance and female submission, characteristics ofthe patriarchal Brazilian society (García, 2014). The socially-constructed notion of male superiority and the concept of women as subservient and as a possession of men can foster sexual abuse occurrence against girls as they age (Carter, 2015; Sorj, 2013). Psychological violence can also be present in sexual abuse episodes, with stigmatization and deprecation being used to prevent victim's disclosure, or to discredit their story (Spiegel, 2003).

In all victims' developmental stage, males tended to be more physically and psychologically abusive. This is specifically remarkable, considering that child care is a task socially attributed to female caregivers (De Antoni \& Koller, 2012). Despite the significant prevalence of female perpetrators, more cases involving male perpetrators may have reached the health system due to their severity. Studies show that men may have a greater tendency to display violent behavior and adhere to rigid gender norms. This behavioral trend is more prominent when they do not see themselves as able to perform the social role of male or when they face situations that require practices considered to be feminine (Baugher \& Gazmararian, 2015; Gallagher \& Parrott, 2011). Men also tend not to recognize or access social support resources, as they might value notions of individuality and competition. It may lead them to be abusive towards children while performing their parental roles (De Antoni \& Koller, 2012; Price-Wolf, 2015). In turn, the higher prevalence of female perpetrators of neglect might be a consequence of the attribution of responsibility for household chores and childcare to women, which may lead them to neglect childrens' needs due to work overload (De Antoni \& Koller, 2012).

\section{Health professionals' responses to cases}

The difficulties in identifying the consequences of child maltreatment are remarkable, resulting in a significant absence of information on the database. The attendance protocols did not specify if the health professionals should evaluate the consequences of child maltreatment through follow-ups. Moreover, no documental proof, such as a medical report, was required to fill up this section of FIN-SINAN (Ministério da Saúde, 2008). These difficulties may have contributed to the exclusion of this section of information from the new version of FIN-SINAN (Ministério da Saúde, 2015).

Regarding the referrals to child protective services, the indication to the Guardianship Council (GC) prevailed. This institution is central to the provision of care for child maltreatment victims, as advocated by the Brazilian law (Law No. $8,069,1990)$. Therefore, the GC would be expected to be present at all referral records. Due to the inexistence of a protocol of assistance for child victims, it was not clear which cases were previously attended by the GC and for which ones the referral would be unnecessary. The standardization of referral procedures on a national level wouldimprove care provision for the victims and enable a satisfactory analysis of its degree of effectiveness across the national territory.

Although prescribed in the Brazilian law (Law No. 12,845, 2013), the rates of prophylaxis for cases of sexual abuse were considered low. The dynamics of this form of maltreatment show that health procedures cannot be based on the victims' narrative once it is required that the child perceives a secure bond to report details of the abuse (Habigzang et al., 2008). Health professionals must consider aspects of sexual abuse dynamics, together with other health practice guidelines, to prevent victims from receiving inadequate prophylaxis due to insufficient information. The data provided by FIN-SINAN does not clarify whether there were other reasons for the lack of performance of these procedures.

Regarding the maltreatment confirmation status, the health professionals' classified the majority of cases as "confirmed". As the victims aged, however, the confirmation levels decreased. This might be explained by the higher prevalence of sexual abuse in middle childhood and the difficulties to confirm this type of maltreatment (e.g., absence of physical signs; long interval between the sexual abuse and the physical examinations; Trindade et al., 2014). The classification of cases as "likely" can also reflect the professionals' fear of reprimands from the victims' family and community, as well as the absence of an institutional policy that preserves the identity of the health professional notifying the case, factors commonly reported by health professionals working in the Brazilian health system (Trindade et al., 2014).

The generalization of results and the discussion herein presented must be carefully considered. The data assessed was collected in the health context, which can bias the direction of the results. Child maltreatment cases that reach the health system are cases that resulted in victims' health impairment (Malta et al., 2016).Therefore, they may not capture the extension of child maltreatment in society. Nevertheless, the results and discussion presented are efficient in describing specificities of child maltreatment cases attended by health professionals in Rio Grande do Sul and characterizes the health professional responses. It also discusses sociocultural aspects that might have influenced maltreatment occurrence. Attention to such aspects may assist health professionals in identifying and responding to cases in daily practice. 
SINAN represents an improvement in the consolidation of epidemiological surveillance of interpersonal violence in Brazil (Assis et al., 2012). However, adjustments are needed to improve the quality of the available information. Investments have been made by public management to improve the epidemiological surveillance based on SINAN, including the improvements to FIN-SINAN between 2008 and 2015. Examples of the modifications added were identification of the violence motivation and the age of alleged perpetrators (Ministério da Saúde, 2015). In addition to such changes, the standardization of a referral model is suggested, which could contribute to the effective provision of healthcare and compilation of information for subsequent assessment. In a broader level, suggestions for preventing child maltreatment would involve targeting development of stable and healthy relationships between children and caregivers, as well asthe promotion of equality between genders, and changes of socio cultural patterns that instigate and tolerate maltreatment against children (WHO, 2014).

Our study contributes to the understanding of child maltreatment by considering specificities of children developmental stages and cultural aspects that can interact to shape its occurrence. Its results permit to shape preventive actions and education of health professionals to improve this important epidemiological control action. A limitation of our study, is the absence of control over data collection procedures, since the report forms were completed according to the health professionals' judgment and based on their knowledge of child maltreatment. Furthermore, we analyzed the cases identified in the health system, thus, results generalization must be done with care. No conflict of interest was identified.

\section{References}

Alves, M. F. A., Silva, B. O., \& Silva, E. G. (2012). Abuso sexual na infância e adolescência: Perfil social e médicoassistencial no centro de referência de Belém [Sexual abuse in childhood and adolescence: Social and medicalcare profile in the center of reference of Belém]. Revista Paraense de Medicina, 26(2), 1-8.

Assis, S. G., Avanci, J. Q., Pesce, R. P., Pires, T. O., \& Gomes, D. L. (2012). Notificações de violência doméstica, sexual e outras violências contra crianças no Brasil [Domestic, sexual and other violences notification against children in Brazil]. Ciência \& Saúde Coletiva, 17(9), 2305-2317. doi:10.1590/ S1413-81232012000900012

Macedo, D.M., Foschiera, L. N., Bordini, T. C. P. M., Habigzang, L. F., \& Koller, S. H. (2019). Revisão sistemática de estudos sobre registros de violência contra crianças e adolescentes no Brasil [Systematic review of studies on reports of violence against children and adolescents in Brazil]. Ciência \& Saúde Coletiva, 24(2), 487-496. doi:10.1590/141381232018242.34132016
Baía, P. A. D., Veloso, M. M. X., Magalhães, C. M. C., \& Dell'Aglio, D. D. (2013). Caracterização da revelação do abuso sexual de crianças e adolescentes: Negação, retratação e fatores associados [Characterizing children and adolescence sexual abuse disclosure: Denial, disclaimer, and associated factors]. Temas em Psicologia, 21(1), 193202. doi:10.9788/TP2013.1-14

Baugher, A. R., \& Gazmararian, J. A. (2015). Masculine gender role stress and violence: A literature review and future directions. Aggression and Violent Behavior, 24, 107-112. doi:10.1016/j.avb.2015.04.002

Belsky, J. (1993). Etiology of child maltreatment: A developmental-ecological analysis. Psychological Bulletin, 114(3), 413-434. doi:10.1037/0033-2909.114.3.413

Boudreaux, M. C., \& Lord, W. D. (2005). Combating child homicide: Preventive policing for the new millennium. Journal of Interpersonal Violence, 20(4), 380-387. doi: $10.1177 / 0886260504269569$

Bronfenbrenner, U. (1994). Ecological models of human development. In M. Gauvain \& M. Cole (Eds.), Readings on the development of children (2nd ed., pp. 37-43). New York, NY: Freeman.

Carter, J. (2015). Patriarchy and violence against women and girls. The Lancet, 385(9978), e40-e41. doi:10.1016/S01406736(14)62217-0

Cicchetti, D., \& Valentino, K. (2006). An ecologicaltransactional perspective on child maltreatment: Failure of the average expectable environment and its influence on child development. In D. Cicchetti \& D. J. Cohen (Eds.), Developmental psychopathology: Vol. 3. Risk, disorder and adaptation (2nd ed., pp. 129-201). Hoboken, NJ: John Wileys \& Sons.

De Antoni, C., \& Koller, S. H. (2012). Perfil da violência em famílias com história de abuso físico [Violence profile amongst families with physical abuse history]. In L. F. Habizang \& S. H. Koller (Orgs.), Violência contra crianças e adolescentes (pp. 43-54). Porto Alegre, RS: Artmed.

Delfino, V., Biasoli-Alves, Z. M. M., Sagim, M. B., \& Venturini, F. P. (2005). A identificação da violência doméstica e da negligência por pais de camada média e popular [Domestic violence and negligence identification by middle and populat classes parents]. Texto \& Contexto Enfermagem, 14(Spe.), 38-46. doi:10.1590/S0104-07072005000500005

Donoso, M. T. V., \& Ricas, J. (2009). Perspectiva dos pais sobre educação e castigo físico [Parent's perspective on child rearing and corporal punishment]. Revista de Saúde Pública, 43(1), 78-84. doi:10.1590/S0034-89102009000100010

Gallagher, K. E., \& Parrott, D. J. (2011). What accounts for men's hostile attitudes toward women? The influence of hegemonic male role norms and masculine gender role stress. Violence Against Women, 17(5), 568-583. doi:10.1177/1077801211407296 
García, A. M. (2014). Prevention of gender-based violence in the classroom: Some observations. Procedia - Social and Behavioral Sciences, 161, 275-280. doi:10.1016/j. sbspro.2014.12.071

Habigzang, L. F., Koller, S. H., Stroeher, F. H., Hatzenberger, R., Cunha, R. C., \& Ramos, M. S. (2008). Entrevista clínica com crianças e adolescentes vítimas de abuso sexual [Clinic interview with sexually abused children and adolescents]. Estudos de Psicologia (Natal), 13(3), 285-292. doi:10.1590/ S1413-294X2008000300011

Halim, M. L., Ruble, D., Tamis-LeMonda, C., \& Shrout, P. E. (2013). Rigidity in gender-typed behaviors in early childhood: A longitudinal study of ethnic minority children. Child Development, 84(4), 1269-1284. doi:10.1111/ cdev. 12057

Instituto Brasileiro de Geografia e Estatística. (2011). Características étnico-raciais da população: Um estudo das categorias de classificação de cor ou raça 2008 [Ethnicracial characteristics in the population: A study of skin color or race categories classification]. Rio de Janeiro, RJ: IBGE. Retrieved from http://biblioteca.ibge.gov.br/visualizacao/ livros/liv49891.pdf

Lei No. 8.069. (1990, 13 de julho). Dispõe sobre o Estatuto da Criança e doAdolescente e dá outras providências [Law 8.069 (1990, July 13). Legislates over the Child and Adolescents Rights Statute and decurrent recommendations]. Retrieved from http://www.planalto.gov.br/ccivil_03/leis/L8069.htm

Lei No. 12.845. (2013, $1^{\mathrm{o}}$ de agosto). Dispõe sobre o atendimento obrigatório e integral de pessoas em situação de violência sexual [Law 12.845 (2013, August 1st). Legislates over the compulsory and comprehensive support assistance to victims of sexual violence]. Retrieved from http://www.planalto.gov.br/ccivil_03/_ ato2011-2014/2013/lei/112845.htm

Lynch, J. (2000). Social epidemiology: Some observations about the past, present and future. Australasian Epidemiologist, 7(3), 7-15. Retrieved from https://search.informit.com.au/ documentSummary; $\mathrm{dn}=433223249557305 ;$ res=IELHEA

Lysenko, L. J., Barker, E. D., \& Jaffee, S. R. (2013). Sex differences in the relationship between harsh discipline and conduct problems. Social Development, 22(1), 197-214. doi:10.1111/sode.12002

Malta, D. C., Mascarenhas, M. D. M., Silva, M. M. A., Carvalho, M. G. O., Barufaldi, L. A., Avanci, J. Q., \& Bernal, R. T. (2016). The occurrence of external causes in childhood in emergency care: Epidemiological aspects, Brazil, 2014. Ciência \& Saúde Coletiva, 21(12), 3729-3744. doi:10.1590/1413-812320152112.17532016

Meier, M. H., Slutske, W. S., Heath, A. C., \& Martin, N. G. (2009). The role of harsh discipline in explaining sex differences in conduct disorder: A study of opposite-sex twin pairs. Journal of Abnormal Child Psychology, 37(5), 653-664. doi:10.1007/s10802-009-9309-1
Ministério da Saúde. (2008). Sistema de Informação de Agravos de Notificação - Ficha de Notificação Individual Violencia Interpessoal/Autoprovocada [Notifiable Disease Information System - Individual Notification of Interpersonal/Self-inflicted Violence Form

Ministério da Saúde. (2015). Sistema de Informação de Agravos de Notificação - Ficha de Notificação Individual Violência Interpessoal/Autoprovocada [Notifiable Disease Information System - Individual Notification of Interpersonal/Self-inflicted Violence Form]. Retrieved from http://www.saude.pr.gov.br/arquivos/File/Ficha_Viol_5_1_ Final_15_06_15.pdf

Ministério da Saúde. (2017). Sistema de Informação de Agravos de Notificação [Notifiable Disease Information System]. Retrieved from http://portalsinan.saude.gov.br/

Papalia, D. E., \& Feldman, R. D. (2013). Desenvolvimento humano [Human development] (C. F. M. P. Vercesi, Trans., 12th ed.). Porto Alegre, RS: Artmed.

Price-Wolf, J. (2015). Social support, collective efficacy, and child physical abuse: Does parent gender matter? Child Maltreatment, 20(2), 125-135. doi:10.1177/1077559514562606

Rates, S. M. M., Melo, E. M., Mascarenhas, M. D. M., \& Malta, D. C. (2015). Violence against children: An analysis of mandatory reporting on violence, Brazil 2011. Ciência \& Saúde Coletiva, 20(3), 655-665. doi:10.1590/141381232015203.15242014

Rodriguez, C. M. (2010). Parent-child aggression: Association with child abuse potential and parenting styles. Violence and Victims, 25(6), 728-741. doi:10.1891/0886-6708.25.6.728

Sorj, B. (2013). Arenas de cuidado nas interseções entre gênero e classe social no Brasil [Ring of care in the intersection between gender and social class in Brazil]. Cadernos de Pesquisa, 43(149), 478-491. doi:10.1590/S010015742013000200006

Spiegel, J. (2003). Sexual abuse of males: The SAM model of theory and practice. New York, NY: Routledge.

Trindade, L. C., Linhares, S. M. G. M., Vanrell, J., Godoy, D., Martins, J. C. A., \& Barbas, S. M. A. N. (2014). Sexual violence against children and vulnerability. Revista da Associação Médica Brasileira, 60(1), 70-74. doi:10.1590/1806-9282.60.01.015

United Nations Children's Fund. (2014). Hidden in plain sight: A statistical analysis of violence against children. New York, NY: UNICEF.

Weber, L. N. D., Viezzer, A. P., Brandenburg, O. J., \& Zocche, C. R. E. (2002). Famílias que maltratam: Uma tentativa de socialização pela violência [Families that commit maltreatment: An attempt of socialization through violence]. Psico-USF, 7(2), 163-173. doi:10.1590/S141382712002000200005 
World Health Organization, \& International Society for Prevention of Child Abuse and Neglect. (2006). Preventing child maltreatment: A guide to taking action and generating evidence. Geneva, Switzerland: WHO. Retrieved from https://www.who.int/violence_injury_prevention/ publications/violence/child_maltreatment/en/

World Health Organization. (2014). Global status report on violence prevention 2014. Geneva, Switzerland: WHO. Retrieved from https://www.who.int/violence_injury_ prevention/violence/status_report/2014/en/

Davi Manzini Macedo is a post doctoral researcher at the University of Adelaide, Adelaide-SA, Australia.

Priscila Lawrenz is a PhD student at the Pontificia Universidade Católica do Rio Grande do Sul, Porto Alegre-RS, Brazil.

Jean Von Hohendorff is an Associate Professor at the Faculdade Meridional, Passo Fundo-RS, Brazil.

Clarissa Pinto Pizarro Freitas is an Associate Professor at the Pontifícia Universidade Católica do Rio de Janeiro, Rio de Janeiro-RJ, Brazil.

Silvia Helena Koller is a Professor at the Universidade Federal do Rio Grande, Rio Grande-RS, Brazil.

Luisa Fernanda Habigzang is an Associate Professor at the Pontifícia Universidade Católica do Rio Grande do Sul, Porto Alegre-RS, Brazil.

\section{Authors' Contribution:}

All authors made substantial contributions to the conception and design of this study, to data analysis and interpretation, and to the manuscript revision and approval of the final version. All the authors assume public responsibility for content of the manuscript.

Received: Oct. 30, 2017

1st Revision: Apr. 11, 2018

2nd Revision: May. 31, 2018

Approved: Jun. 05, 2018

How to cite this article:

Macedo, D. M., Lawrenz, P., J. Hohendorff, J. V., Freitas, C. P. P., Koller, S. H., \& Habigzang, L. F. (2020). Characterization of child maltreatment cases identified in health services. Paidéia (Ribeirão Preto), 30, e3018. doi:http://dx.doi.org/10.1590/1982-4327e3018 